\title{
Research on Labor Subcontracting Problem and Countermeasures in Construction Engineering Market Summary
}

\author{
Ran Zhang \\ Administrative Engineering College, Zhengzhou University, No.100 Science Avenue, Zhengzhou, \\ China
}

Keywords: construction engineering; labor subcontracting; trading platform

\begin{abstract}
At present, China's construction industry is in a period of rapid development, and the development of labor subcontracting in the construction engineering market is becoming more and more perfect, but there are still many problems, which are of great significance to its research. Through the field research on several projects under construction in Xinzheng, using the methods of interviews and the methods of consulting the literature, it is found that the current subcontracting competition in the construction engineering market is quite fierce and in a very chaotic situation. There are construction enterprises that are not standardized in selecting labor subcontracting teams, and lack of control over labor subcontracting; labor subcontracting enterprises have a small scale of development and lack of ability to resist risks. Subcontracting market supervision is still not in place. This paper puts forward corresponding countermeasures from the perspectives of construction construction enterprises, labor subcontracting enterprises and government for the above problems of labor subcontracting in the construction engineering market.
\end{abstract}

\section{Introduction}

In recent years, China's construction industry has developed rapidly. The government has vigorously built infrastructure projects. The real estate industry has also been developing at a high speed. The total output value of the construction industry has increased from 1,372,178 million yuan in 2012 to 193,566.78 billion yuan in 2016. A trend of modern development has emerged. . The labor force played a key role in the construction of modern large-scale engineering projects. In recent years, the number of labor subcontracting enterprises has increased from 6,756 in 2011 to 8,122 , and the total number of migrant workers in the city has continued to increase. The construction industry is a labor-intensive industry. People are one of the most important factors, and now the fierce competition in the construction industry has led to shorter and shorter construction projects, higher quality requirements, and higher requirements for labor allocation. At the present stage, the construction engineering market is still not perfect, and gradually reveals the drawbacks of the construction labor market management. The choice of subcontracting is very random, and the labor subcontracting bidding system is not strict enough. The phenomenon of undocumented contracting, illegal subcontracting, contractor, and anchoring is everywhere, and the management 
level cannot keep up. The quality of the project does not meet the requirements. There are security risks. The arrears of wages of migrant workers and the low quality of laborers(Gao Xiang,2012). Solving these problems will help the labor subcontracting in the construction engineering market to be more standardized and healthy.

\section{Engineering project labor subcontracting and related theory}

\subsection{Overview of Engineering Project Labor Subcontracting}

\subsubsection{The Concept of Labor Subcontracting}

Labor subcontracting refers to the activities carried out by the construction general contracting enterprise or professional contracting enterprise to contract the labor service in the contracted building and municipal infrastructure project contracted to the labor service subcontracting enterprise with corresponding qualifications (Mijia, 2017).

\subsubsection{Legal Nature of Labor Subcontracting}

The labor subcontract is a contract. As far as subject qualification is concerned, the contractual relationship is not a specific subject, but there are certain qualification restrictions (Feng Jincai, 2008). According to the provisions of the "Construction Enterprise Qualification Management Regulations" and "Building Construction and Municipal Infrastructure Engineering Subcontract Management Measures", only the construction of the project has been undertaken. The construction general contracting enterprise or professional contracting enterprise can be the construction labor contractor, and only the labor subcontracting enterprise with the corresponding qualification can be the contractor. As far as the payment target is concerned, in the labor subcontracting, the labor service remuneration of the construction labor subcontracting is not only the value of the labor force, but also the direct fee, the indirect fee and the profit. The organization of labor service activities is to obtain compensation according to the labor results, instead of According to the value of the labor force (Mijia, 2017).

\subsection{Analysis of Current Status of Labor Subcontracting in Construction Engineering Market}

\subsubsection{Development of Labor Subcontracting Enterprises}

China's construction industry labor subcontracting began to develop in 2001. After several years of development, the labor subcontracting market has basically taken shape in China. According to the statistics of the National Bureau of Statistics, the number of labor subcontracting enterprises in China was 1,193 in 2002, and the number increased to 8122 in 2016, an increase of about seven times. The proportion of subcontracting enterprises to the total number of construction enterprises increased from 2.49\% in 2002 to $13.36 \%$ in 2016, and the number of employees in labor subcontracting enterprises also increased rapidly, from 343,755 in 2002 to 31,256,615 in 2016. , increased by about nine times.

\subsubsection{Supply and Demand, Structure and Work Characteristics of Construction Workers}

(1) The increase in the supply of construction laborers has gradually decreased

In recent years, China's real estate industry has developed rapidly, and the state has also intensified its infrastructure construction, and labor demand has increased significantly. However, 
although the construction industry is gradually increasing, the overall increase is gradually decreasing.

(2) The construction workers have a low level of education and are aging.

At present, the problem of the aging of laborers in the construction industry in China is very serious, and the phenomenon of recruitment difficulties is already very serious. After the 1990s, a new generation of migrant workers are reluctant to enter the construction industry, and construction workers account for a large part of the age of 40. A survey of several sites in Xinzheng found that construction workers accounted for $78 \%$ of those aged 35 to 50, and 15\% of those aged 25 to 35 . Others were laborers over 50 years old. The survey found that the education level of these construction workers is generally low, most of them are junior high school and below.

\section{Main problems and analysis of labor subcontracting in construction engineering market}

\subsection{The Main Problems and Analysis of Construction Enterprises in Labor Subcontracting}

\subsubsection{Problems in the Selection of Labor Subcontracting Teams}

In the decoration project of an art center in Xinzheng, the project cost about 10.5 million yuan, belonging to a medium-sized project, which is a project that needs to be tendered. It is understood that when the construction general contracting enterprise chooses subcontracting sub-suppliers before construction, it first contacts some subcontractors who have previously cooperated to let them bid, and the public bidding is only formal. Since a subcontractor was a friend of the project leader, a verbal agreement was reached in private and no written agreement was signed. In this way, the division of responsibilities between the two parties is rather vague, which leads to the failure of the two parties to reach a consensus when the project is settled. From this example, the following questions can be analyzed:

(1) Subcontracting team selection is not standardized

Most of the processing units' choices for labor subcontracting teams are arbitrary. There is no clear selection criteria, not objective, but subjective choice. In addition, the implementation of the bidding process of the subcontracting team is not formal, the subcontracting team used is rather messy, the social background is more complicated, the management is difficult and the management resistance is large. Most of the laborers on the construction site are fellow villagers or relatives and friends. Such a relationship is hinder to the management of management personnel(Yan Libin,2012). There are also some labor service teams with special backgrounds who dare to violate the orders of the construction units, resulting in passive project management.

(2) Lack of perfect subcontract management

The management of labor subcontracts is very important, but some construction companies pay more attention to it. Under normal circumstances, construction companies only conduct verbal consultations with labor subcontractors or sign simple written agreements without signing. Formal labor contracts, so the responsibilities and obligations of both parties are not clearly defined, and it is easy to form a management loophole. Some labor subcontracting companies can rely on these loopholes to make opportunistics at the time of settlement. At this time, the construction enterprises have nowhere to argue (Qu Yuping, 2017).

(3) There is a phenomenon in which Party A assigns subcontracting

The so-called "subcontracting" by Party A means that the general contracting enterprise must attach a labor subcontract to the contract in order to accept the project from the contract of Party A, that is, let Party A designate the labor subcontracting team (He Manhong, 2013).The biggest disadvantage of Party A's assignment of subcontracting to construction companies is that the settlement right of the project is dominated by the developer. In addition, it is difficult for the 
construction enterprise to carry out effective management with the labor force assigned by Party A. The difficulty of coordination between the two parties will lead to slow progress and the quality of the project is difficult to guarantee.

\subsubsection{Problems in the Control Process of the Construction Process}

(1) Lack of effective control over secondary subcontracting of labor services.

Although China does not allow labor subcontracting and subcontracting at present, the phenomenon of secondary subcontracting in this industry is still very serious. Under normal circumstances, the general contracting enterprise or professional contracting enterprise tends to choose the strength when selecting the labor subcontracting enterprise, but the construction team selected by the labor subcontracting enterprise for the economic benefit in the process of subcontracting has no strength guarantee. So the actual construction team is often led by the contractor. This actual construction team does not have the corresponding qualifications and technical strength, and has no ability to resist risks (Kong Xiangliang, 2016). This will easily cause many problems. For example, once the project funds are not in place, it is easy for the contractor to run the road and the migrant workers to petition. It is easy to cause social instability.

(2) There is a lack of control over labor subcontracting during the construction process.

Under the current circumstances, during the construction process, the management method of the construction unit is not detailed enough, especially for the textual materials in the construction process, the text information is not accurate enough. For example, the construction log is missing, the technical disclosure is only a walking form, and the material waste is serious. problem. In addition, during the construction process, the labor subcontracting team only works on large, easyto-dry jobs, and those small parts and difficult parts are left for later processing, so that they may be missed in the future, and the quality of the project cannot be guaranteed. This is due to the lack of effective process control in the construction unit.

\subsubsection{Analysis of the Causes of Problems in the Process of Subcontracting Labor Services}

(1) Internal factors of the enterprise

The construction company lacks standardized operating procedures for bidding. A perfect bidding process will help the construction company to allocate the working surface reasonably and verify the engineering quantity. However, when the construction enterprise chooses the labor subcontracting team, many construction enterprises are not standardized on the bidding process, and skip some in order to save trouble when going through the process. Steps, this will not guarantee the strength and quality of the labor force, it will lead to various troubles in the later construction process, such as the disconnect between the construction teams. In addition, the non-standardization of bidding work is also likely to cause some legal loopholes and increase the difficulty of management of construction enterprises.

(2) External factors of the enterprise

First, the education level of laborers is low. Most of them are migrant workers. They are older and have poor skills. Therefore, the rate of holding a certificate is low. The survey found that 55\% of workers have no certificate, and the main way for them to acquire skills. It is through the mentoring relationship that the newcomers who have just entered the construction site are carried by the old man. Second, the number of migrant workers in the labor market is currently tight. In particular, the number of migrant workers in the new generation is very small, and there is a gap in technology and experience (Huang zhonghao,2014). 


\subsection{The Main Problems and Analysis of Labor Subcontracting Enterprises}

\subsubsection{Most Labor Companies do not have the Ability to Resist Risks}

The labor service company is registered as a limited liability company in the industrial and commercial registration. The liability of the shareholders is limited to the amount of capital contribution, and all the assets of the legal person bear the debt liability (Ren Wei, 2014). However, the labor company must obtain legal qualifications for business activities. According to the qualifications of construction enterprises, the registered capital of labor companies is 300,000 yuan to 500,000 yuan. There is basically no requirement for fixed assets in labor service companies. After obtaining industrial and commercial registration and qualifications, there are cases where registered capital is fleeing, renting office space or no office space at all. Therefore, the shareholders can not bear the debt on the amount of capital contribution, and the legal person does not have the fixed assets to bear the debt. If a labor contract is signed, if the contractor does not pay attention to or consider the anti-risk ability of the labor subcontracting enterprise, and expand the contracted business scope and supplementary capital operation at will, contract disputes are inevitable. The labor service company's ability to resist risks is weak. Once the operating loss occurs, the legal representative is easy to escape. This is unfavorable for maintaining the legitimate rights and interests of construction enterprises and laborers.

\subsubsection{The Technical Standards Implemented by Labor Enterprises Fail to Meet the Prescribed Standards}

According to the construction enterprise qualification management regulations, the labor service company only needs the corresponding professional assistant engineers, technicians or senior technical personnel in the industry, qualified technical workers; the number of skilled workers must meet the qualification requirements, and the technical standards are implemented. Technical Operation Procedures. It can be seen that the labor service company can only provide labor services, as long as the number of labor workers can fulfill the labor subcontract. The main task of the enterprise technical leader is to train the workers according to the construction technical operation rules and guide the workers' operations. The company's quality responsibility is to ensure that the technical personnel engaged in the position have the technical level suitable for the position and technical management of the workers' operation process. It is equipped with the person in charge of construction technology, construction personnel, quality inspection personnel, safety personnel, materials personnel, data personnel, etc., which obviously exceeds the technical capabilities and technical level of the labor service company. Unqualified engineering quality or quality accidents are inevitable.

\subsubsection{The Number of Labor Subcontracting Enterprises is too Small}

At present, there are only over 8,000 registered labor subcontracting enterprises in China, and the truly qualified labor subcontracting enterprises are in a tight supply in this booming construction market (Su Jinming, 2009). On the one hand, the approval procedures for the establishment of labor subcontracting enterprises in China are complicated. Some powerful contractors are not willing to bother in order to save costs, and the willingness to form labor subcontracting enterprises is low. The complexity of the approval procedures restricts the labor subcontracting enterprises. The development of quantity. On the other hand, most of the migrant workers have low quality, no organizational discipline, scattered teams and lack of necessary skills training, so it is difficult to use the development of the construction industry, which hinders the migrant workers from entering 
the construction industry to a certain extent, thus hindering The development of the number of labor enterprises.

4. Countermeasures and suggestions for improving labor subcontract management in the construction engineering market

\subsection{Countermeasures for the General Contracting Enterprises of Construction}

\subsubsection{Strengthen the Management of Labor Enterprise Norms, and Cooperate with Labor Subcontracting Enterprises to Achieve Win-Win Cooperation}

On the one hand, the labor subcontracting enterprise is the first line operation in the construction of the project, the first responsible party of the project quality, and responsible for the organization and management of the project, so it is imperative for the construction enterprise to strengthen the management of the labor enterprise. Construction enterprises should strengthen the management of labor enterprises, strengthen the project management, change the current wage distribution model of labor enterprises, and pay the wages of workers. At the same time, construction enterprises should strengthen the legal publicity activities of the construction labor industry and reduce The threshold of rights protection for laborers allows them to know how to defend their rights. On the other hand, construction enterprises can carry out long-term cooperation with labor subcontracting enterprises, sign a joint development cooperation agreement, help labor subcontracting enterprises to go to market and standardize management, and sign labor contracts and purchase insurance with laborers. This is conducive to solving the problem of difficult management of construction enterprises, and is also conducive to solving the loss of talents in construction enterprises, which is conducive to the improvement of the technical level of construction enterprises.

\subsubsection{Selecting Labor Subcontracting Enterprises should be Cautious}

Construction general contracting should be thoroughly investigated when selecting labor subcontracting enterprises. First, it is necessary to face the society, in accordance with the formal process, transparent implementation of bidding, select labor, sub-contracting enterprises with strength, technology and easy management, should follow the labor tendering procedures.

Second, the selected labor subcontracting enterprises must conduct a rigorous inspection, and should consider comprehensively from the aspects of enterprise qualification, construction level and organization level. Of course, it is very important to have certain capital advancing ability, so that it can effectively avoid Some risks(Wang Shijun. 2012).

\subsubsection{Strengthening the Construction of Labor Subcontracting Team}

Construction general contracting enterprises should establish their own labor supply information system. In this way, they can better select high-quality labor subcontracting teams, thus improving the management level of labor subcontracting. Further, although the two-layer separation is now advocated, this can save costs and improve market vitality (Tang Xiuwei. 2017). However, in the construction process, management is somewhat inconvenient, so the construction company can also retain its own construction team, so that the established labor force Although it requires a lot of manpower, material and financial resources, the stability of the team can be guaranteed, and control over technology and control. 


\subsection{Countermeasures for Labor Subcontracting Enterprises}

\subsubsection{Compliance with Laws and Regulations for Healthy Development}

Labor subcontracting enterprises must resolutely abide by national laws and regulations, and resolutely avoid subcontracting labor services to other labor teams or subcontracting to other construction labor companies. At the same time, it is necessary to strengthen the training of its own labor service personnel, carry out training for technical leaders, management personnel and laborers, improve their business level, and achieve healthy and stable development of enterprises.

\subsubsection{Enhance Anti-risk Ability by Merging or Acquiring Small Labor Subcontracting Enterprises}

At present, in the subcontracting market for construction engineering labor services, there are still a small number of labor subcontracting enterprises, most of which are small-scale labor subcontracting enterprises with insufficient funds and weak anti-risk ability (Jin Yueliang, 2009). Due to the low registration threshold of labor subcontracting enterprises in China, a labor service company can be registered for 300,000-500,000 yuan, and its own strength is still relatively weak. Therefore, on the one hand, two or several smaller labor subcontracting enterprises can be merged, or large labor subcontracting enterprises can enhance their own strength by acquiring small labor subcontracting enterprises. On the other hand, they can also the foreman team will enhance their own strength and achieve the effect of zeroing, so that the ability to prevent risks will increase greatly.

\section{Summary and outlook}

The labor subcontracting problem in the construction engineering market has been a hot issue for many scholars. With the continuous development of China's construction industry, the improvement of the construction engineering market is also an inevitable trend, and the solution of labor subcontracting problems is just around the corner. Through the analysis of the government, construction general contracting enterprises and labor subcontracting enterprises, this paper draws the following conclusions: To solve the labor subcontracting problem in the construction engineering market, it must pass the government, construction enterprises and labor subcontracting enterprises. The joint efforts of the parties to solve the problem, the government must improve the relevant rules and regulations, so that there are laws to follow, there are rules to follow, so that construction companies and labor subcontracting enterprises to act according to the rules, the use of modern means to establish an information platform, so that labor services The package is open and transparent; the general contracting enterprise must strengthen the management level, standardize the labor subcontracting bidding mechanism, and strengthen the contract management; the labor subcontracting enterprises should continue to be bigger and stronger, and enhance their ability to resist risks. After solving the labor subcontracting problem through several aspects, the construction engineering market must be stable and healthy development.

\section{References}

[1] Feng Jincai, Wang Bingsheng. 2008. Research on the status quo and countermeasures of labor subcontract management in construction enterprises [J]. Construction Economy, (04): 107-110.

[2] Gao Xiang. 2012. Talking about the status quo and development trend of labor subcontracting [J].Science and Technology, (04):268.

[3] He Manhong. 2013. Current status and countermeasures of labor subcontract management in the construction industry [J]. Zhonghua Construction, (07): 80-81. 
[4] Huang Zhonghao. 2014. Research on Peasant Workers and Labor Subcontract Management in Construction Industry [J]. Oriental Enterprise Culture, (01): 147-148.

[5] Jin Yueliang. 2009. Research on subcontracting of construction services and its bargaining mechanism [D]. Southwest Jiaotong University.

[6] Kong Xiangliang. 2016. Research on the Subcontracting Mechanism of Construction and Construction Labor Services [J].Residential and Real Estate, (36):271.

[7] Mi Jia. 2017. Analysis of subcontracting, subcontracting and labor subcontracting [J]. Shanghai Construction Technology, (05): 81-84.

[8] Qu Yuping. 2017. Exploring the Management of Engineering Labor Contracts [J]. Value Engineering, 36(03): 4951.

[9] Ren Wei. 2014. Problems in the management of construction labor service companies and countermeasures [J]. Chinese and foreign entrepreneurs, (03): 55-56.

[10] Su Jinming, Liu Jiaxi. 2009. Current Situation and Countermeasures of Engineering Labor Subcontracting Market [J].Shanxi Architecture, 35(22):215-216.

[11] Tang Xiuwei. 2017. Analysis of Labor Subcontract Management in Construction Enterprises [J]. Building Materials and Decoration, (32): 141-142.

[12] Wang Shijun. 2012. On the status quo and development countermeasures of subcontract management of construction labor services [J]. Science and Technology Information, (09): 61.

[13] Yan Libin. 2011. Analysis and development of the status quo of labor subcontracting in the construction sector [D]. Xi'an University of Architecture and Technology. 